\title{
Interview with Professor dr. Daniella Tilbury
}

\section{Majda Naji}

Envigogika 9 (1) - Inspirations/ Inspirace

Published/ Publikováno 30. 5. 2014

DOI: $\underline{10.14712 / 18023061.443}$

Rozhovor s prof. Daniellou Tilbury 


\section{Questions: Majda Naji, Answers: Daniella Tilbury}

In my role as an assistant researcher for GE and ESD at the International School for Social and Business Studies (ISSBS) and the former Slovenian representative at the UNECE I'm constantly following what has been achieved in this area in education. This year will mark the end the United Nations Decade in Education for Sustainable Development (2004 2014) known as DESD. I therefore contacted Professor Daniella Tilbury, Dean of Sustainability at The University of Gloucestershire, UK, and Chair of the UNESCO Global Monitoring and Evaluation Expert Group, known as MEEG, who kindly accepted my request. We corresponded electronically and her answers were delivered by email. A short version of this interview will be published in the Central Slovenian newspaper Delo.

\section{How can the DESD be described in brief?}

The United Nations Decade in Education for Sustainable Development (otherwise known as the DESD) is a global movement which seeks to transform education policy, investment and practice. Spanning 2005 to 2014, the ultimate goal of the DESD is to engage people and communities in meaningful lifelong learning processes which examine how societies can live in more sustainable ways. The scope of the DESD is broad and its potential effects are far-reaching. If it is successful, the DESD could transform not only education but also the quality of life for many people across the globe.

\section{What was the role of MEEG (Monitoring and Evaluation Expert Group)?}

Acknowledging the potential impact of the DESD, UNESCO established a Monitoring and Evaluation Expert Group (MEEG) in 2007 to advice on appropriate monitoring mechanisms to assess:

(i) global progress in the implementation of the DESD; and

(ii) UNESCO's contribution to the implementation of the DESD.

\section{MEEG has undertaken extensive work. Where has the group been particularly effective?}

The MEEG is comprised of specialists who have expertise and experience in M\&E at the international and national level in the following fields: educational policies and management, educational statistics, ESD, environmental education, social development and economics of development. The Expert Group has been effective in providing informed guidance on the preparation and implementation of the global Monitoring and Evaluation (M\&E) framework for the DESD, drawing on the M\&E approaches developed by the Europe and Asia-Pacific regions and the existing M\&E systems of other UN global initiatives:

- $\quad$ EFA (Education for All),

- UNLD (UN Literacy Decade),

- $\quad$ EDUCAIDS (Global Initiative on Education and HIV and AIDS) and

- MDGs (Millennium Development Goals). 


\section{How many implementation reports has the MEEG recommended?}

After its first meeting in 2007, the MEEG recommended that UNESCO publish three DESD implementation reports during the life of the Decade:

1. Phase in 2009: focusing on the context and structures of work on ESD in Member States;

2. Phase in 2011: focusing on processes and learning initiatives related to ESD; and

3. Phase in 2015: focusing on impacts and outcomes of the DESD.

\section{Phase I (2007-2009) of the DESD focused on the context and structures of ESD. What were the main findings?}

Phase I of the DESD M\&E process was underpinned by the Global Monitoring and Evaluation Framework (GMEF) which was comprised of 5 mutually supportive components:

- Questionnaire;

- Complementary desktop research;

- Multi-stakeholder consultation process (MSCP); and

- UNESCO portfolio of evidence.

Phase 1 found that there have been significant policy and structural developments around the world with investment by governments, agencies and bodies to promote ESD at the national level. New policies had been developed, departments restructured to assume responsibilities in this area and national focal points identified. The study acknowledged the significant investment that had been made by countries such as Japan, Canada, Australia, Sweden and Denmark within their countries but also through international collaboration and aid. The report showcased examples from around the globe where measures where been taken to embed sustainable development into educational structures and education into sustainability frameworks and policy developments.

\section{Phase II (2010 -2012) focused on processes and learning in ESD. Would you please explain the meaning of these two phrases?}

Phase II of the DESD M\&E process focused on processes and learning for ESD. To succinctly explain the phrase processes and learning for ESD:

"Processes" implies approaches, focus, and teaching and learning styles adopted to implement ESD in different types, levels and settings of education.

"Learning" for ESD seeks to document what has been learnt by those receiving ESD as well as by those funding or facilitating learning opportunities in this area.

\section{What kind of evidence basewas used in Phase 2?}

Phase II looked at what has begun to change since the outset of the Decade. The report's evidence base was generated through key informant surveys, regional synthesis reports, learning-based case studies and national ESD journeys, as well as through extensive use of exemplary anecdotes, case study excerpts and reflections that capture the essence, 
richness and challenges of ESD in practice. The trends and patterns captured in the Phase II identified have not been presented in ways that characterize a specific country or region, as they can be found across the globe, although they manifest themselves more strongly in some areas than in others.

\section{What were the main findings of Phase 2?}

The report found that dealing with sustainability issues requires more integrative, problem-based and exploratory forms of learning that also invite participants to be critical, creative and change-oriented. This requires a rethink or reorientation of existing practices found in schools, colleges or Universities. The study recorded the rise of 'whole-institution approaches' to ESD where there was connected learning - in other words a linking of what the education institution did and what it taught. Sustainable campuses and green schools are in the increase marking a global trend.

\section{Which teaching and learning approaches are essential in ESD?}

It also suggested that ESD was associated strongly with participatory and student centred learning approaches. The report also identified visionary leadership, social networking, new forms of research and high levels of participation as key elements of ESD. The boundaries between schools, universities, communities and the private sector are blurring helping students connect what they are learning in the classroom with real life. The study also identified the need for citizens and learners deal with complexity, controversy and uncertainty which underpin current scenarios. These are important to the health of our planet and our wellbeing as a people.

\section{Where will the UNESCO World Conference on ESD take place and what is the main purpose of the meeting?}

The World Conference is scheduled to take place in Achi-Nagoya on the $10-14^{\text {th }}$ November 2014 with stakeholder groups and side events taking place at Okayama between the $4-8^{\text {th }}$ November. This UNESCO Conference will mark the end of the Decade and is organised in collaboration with the Japanese Ministry of Education, Culture, Sports, Science and Technology (MEXT).

Under the banner of "Learning Today for a Sustainable Future", the Conference will celebrate the achievements of the Decade, identify lessons learnt and set the stage for the future of Education for Sustainable Development. It will also showcase initiatives, actors, networks and ideas that the Decade has stimulated. Such examples from all over the world will help to generate future action.

\section{What we have learned from the main findings of Phase 3 ?}

I am unable to answer your question on what has been achieved as the results of the third report are yet to be unveiled. These findings will be presented at Nagoya and researchers and evaluators are busy at present collecting and validating data from across the global regions to ensure that the report is representative and accurate. 


\section{The ESD journey will go on after 2014. Would you please describe the Global Action Programme (GAP)?}

Following a request from its Executive Board, UNESCO initiated a consultation process with countries and to frame a Global Action Programme (GAP) on ESD. This stakeholder engagement process was underpinned by a UNESCO questionnaire to which responses were received from around 100 Member States and over 500 other stakeholders such as nongovernmental organizations and United Nations agencies; regional consultation meetings; as well as online consultations of the United Nations Interagency Committee for the DESD, the International Steering Group for the UNESCO World Conference on ESD in 2014, the DESD Reference Group and the Working Group of UNESCO Chairs on ESD. The DESD Monitoring and Evaluation Expert Group and participants of the UNESCO Youth Forum were consulted electronically.

\section{Is there a link between GAP and the Rio+20 Conference?}

The Programme seeks to "address education at all levels and in all forms" and is "based on a comprehensive sustainable development agenda, while also encouraging strategic focus and national commitment." UNESCO will work with partners to develop activities in the priority action areas of the Global Action Programme. The GAP, as it is otherwise known, will engage with the post-2015 development agenda and the outcome document of the Rio+20 conference, "The Future We Want", notably paragraphs 229-235. It is expected to be launched and a roadmap for its implementation will be presented at the UNESCO World Conference on ESD.

\section{The GAP's overall goals are defined by two objectives. What are these?}

The overall goal of the draft Global Action Programme is "to generate and scale-up action in all levels and areas of education and learning in order to accelerate progress towards sustainable development". This goal is further defined by two objectives:

(a) to reorient education and learning so that everyone has the opportunity to acquire the knowledge, skills, values and attitudes that empower them to contribute to sustainable development; and

(b) to strengthen education and learning in all agendas, programmes and activities that promote sustainable development.

\section{What are the key points in the ESD agenda?}

Five priority action areas are emerging as key leverage points to advance the ESD agenda: (1) policy support; (2) whole-institution approaches; (3) Educators; (4) Youth; and (5) local communities.

It is early days for the GAP and thus difficult to ascertain its potential to embed ESD in policy and practice across the globe. To date, stakeholders are optimistic about the opportunities it presents and the possibilities that could result from such international collaboration. 
Professor Tilbury, thank you very much for your interesting and detailed responses. I wish you success in the future and look forward to further cooperation in ESD.

\section{Appendix}

Some sources from the interview are available on the following websites:

1. The United Nations Decade in Education for Sustainable Development (DESD) http://unesdoc.unesco.org/images/0014/001416/141629e.pdf

2. Monitoring and Evaluation Expert Group (MEEG) http://www.unesco.org/new/en/unesco/events/educationevents/?tx_browser_pi $1 \% 5$ BshowUid\%5D $=4486 \&$ cHash=547962e7ce

3. Monitoring and Evaluation (M\&E) framework http://scalingupnutrition.org/wp-content/uploads/2013/05/SUN-MEFramework.pdf

4. Education for All (EFA) http://www.unesco.org/en/education-for-all-internationalcoordination/themes/efa-goals/

5. UN Literacy Decade (UNLD) http://unesdoc.unesco.org/images/0018/001840/184023e.pdf

6. Global Initiative on Education and HIV and AIDS (EDUCAIDS) http://unesdoc.unesco.org/images/0013/001398/139831e.pdf

7. Millennium Development Goals (MDGs) http://www.undp.org/content/undp/en/home/mdgoverview/

8. Phase II (2010-2012): Processes and learning for ESD http://www.unesco.org/new/en/education/themes/leading-the-internationalagenda/education-for-sustainable-development/monitoring-evaluationprocess/phase-ii-2010-2012/

9. Phase I (2007-2009): Contexts and Structures for ESD http://www.unesco.org/new/en/education/themes/leading-the-internationalagenda/education-for-sustainable-development/monitoring-evaluationprocess/phase-i-2007-2009/

10. Global Monitoring and Evaluation Framework (GMEF) http://portal.unesco.org/education/en/files/56743/12254714175GMEFoperationalfi nal.pdf/GMEFoperationalfinal.pdf

11. UNESCO World Conference on Education for Sustainable Development http://sustainabledevelopment.un.org/index.php?page $=$ view $\&$ type $=13 \& n r=466 \& \mathrm{~m}$ enu $=1549$

12. Global Action Programme (GAP) http://www.unesco.org/new/en/unesco-world-conference-on-esd-2014/esd-after-2014/global-actionprogramme/ 


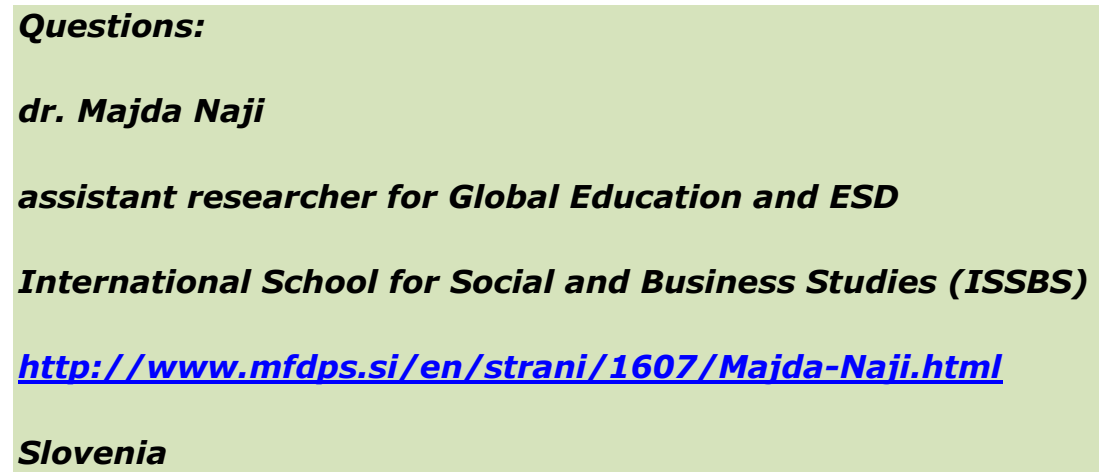




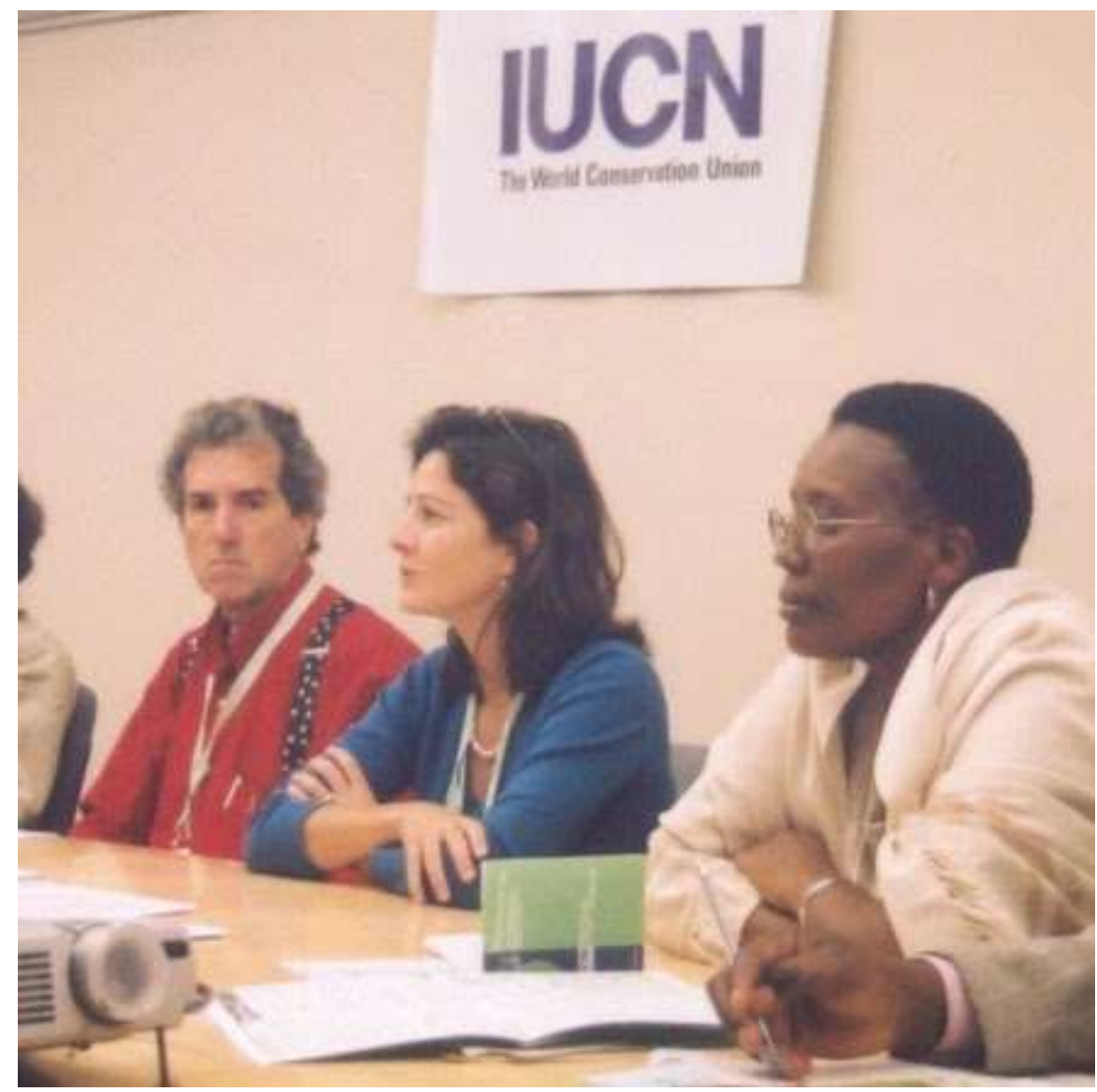

